\title{
PENGGUNAAN MEDIA TANAMAN LOKAL UNTUK MENINGKATKAN AKTIVITAS BELAJAR IPA DI SEKOLAH DASAR
}

\author{
Maria Dolorosa Roru ${ }^{{ }^{*}}$, Nining Sariyyah ${ }^{2}$, Stefanus Tebajak Henakin ${ }^{3}$ \\ 1,2,3 Program Studi PGSD Universitas Flores Ende \\ Jalan Samratulangi, Kelurahan Pupire, Ende, Flores, Indonesia \\ ${ }^{*}$ Corresponding Author: dolorosa322@gmail.com

\section{Info Artikel} \\ Sejarah Artikel: \\ Diterima: 03/08/2020 \\ Direvisi: 06/08/2020 \\ Disetujui:08/08/2020 \\ Keywords: Learning \\ Activities, Local Plant \\ Media

\section{Abstract} \\ The purpose of this study is (1) To find out the Application of Local Plant Media in \\ Increasing Student Learning Activities of Grade IV SDI Onekore 4, Ende Utara District, \\ Ende Regency. (2). To find out the increase in student learning activities in class IV SDI \\ Onekore 4, Ende Utara District, Ende Regency. This type of research used is classroom \\ action research. The subjects in this study were 32 students in grade IV Onekore 4 SDI. \\ Furthermore, data collection techniques are carried out through observation and tests. \\ Based on the results of this study it can be concluded that the use of local plant media to \\ identify science learning activities in class IV SDI Onekore 4 from cycle I to cycle II has \\ increased. Cycle I obtained an average yield of 59.84 and in the cycle obtained an average of \\ 70.80. From the results of the study it can be concluded that the science learning process by \\ using local plant media can increase the learning activities of grade IV students of SDI \\ Onekore 4, Ende Utara subdistrict, Ende Regency.
}

\begin{abstract}
Abstrak
Tujuan dari peneliti ini adalah (1) Untuk mengetahui Penerapan Media Tanaman Lokal Dalam Meningkatkan Aktivitas Belajar Siswa kelas IV SDI Onekore 4 Kecamatan Ende Utara Kabupaten Ende. (2). Untuk mengetahuai peningkatan aktivitas belajar siswa di kelas IV SDI Onekore 4 Kecamatan Ende Utara Kabupaten Ende. Jenis penelitian ini yang digunakan adalah penelitian tindakan kelas. Subjek pada penelitian ini adalah peserta didik kelas IV SDI Onekore 4 yang berjumlah 32 orang. Selanjutnya teknik pengumpulan data dilakukan dengan melalui observasi dan tes. Berdasarkan hasil penelitian ini dapat disimpulkan bahwa Penggunaan media tanaman lokal untuk mengetahuikatkan aktivitas belajar IPA di kelas IV SDI Onekore 4 dari siklus I sampai siklus II mengalami peningkatan. Siklus I diperoleh hasil rata-rata sebesar 59,84 dan pada siklus diperoleh hasil rata-rata sebesar 70,80. Dari hasil penelitian dapat disimpulkan bahwa proses pembelajaran IPA dengan menggunakan media tanaman lokal dapat meningkatkan aktivitas belajar peserta didik kelas IV SDI Onekore 4 kecamatan Ende Utara Kabupaten Ende.
\end{abstract}

\footnotetext{
"Alamat korespondensi:

Program Studi Pendidikan Guru Sekolah Dasar

Fakultas Keguruan dan Ilmu Pendidikan Universitas Flores

Kampus III Universitas Flores, Jln. Samratulangi,

Kelurahan Paupire, Ende, NTT

E-mail: dolorosa322@ gmail.com

() 2020 Program Studi PGSD Universitas Flores Email: primagistrauniflor@gmail.com
} 


\section{PENDAHULUAN}

Ilmu pengetahuan Alam (IPA) merupakan salah satu disiplin ilmu yang berhubungan dengan cara mencari tahu tentang alam secara sistematis sehingga IPA bukan hanya penguasaan kumpulan pengetahuan yang berupa fakta-fakta, konsep-konsep tetapi prinsip-prinsip saja tetapi juga merupakan suatu proses penemuan dan memiliki sikap ilimiah. IPA menurut Trowbridge and Bybee (Purbosari, 2016) sains atau IPA merupakan representasi dari hubungan dinamis yang mencakup tiga faktor utama yaitu "the extant body of scientific knowledge, the values of science and the method and procecces of science" yang artinya sains merupakan produk dan proses, serta mengandung nilai-nilai.

Perkembangan IPA selanjutnya tidak hanya ditandai oleh adanya kumpulan fakta saja, tetapi juga munculnya "metode ilmiah" (scientific methods) yang terwujud melalui suatu rangkaian "kerja ilmiah" (working scienctifi), nilai dan "sikap ilmiah" (scientific attitudes)" (sejalan dengan pengertian tersebut, IPA merupakan suatu rangkaiann konsep yang saling berkaitan dengan bagan-bagan konsep yang telah berkembang sebagai hasil eksperimen dan observasi dan selanjutnya akan selanjutnya akan bermenfaat eksperimentasi dan observasi lebih lanjut.

Merujuk pada pengertian IPA diatas, maka hakikat IPA meliputi empat unsur, yaitu, (1) produk berupa fakta, prinsip, teori dan hukum. (2) proses: yaitu prosedur pemecahan masalah melalui metode ilmiah: metode ilmiah meliputi pengamatan, penyusun hipotesis, perancangan eksperimen, percobaan atau penyelidikan, penguji hipotesis melalui eksperimen, evaluasi, pengukuran dan penarikan sehingga dapat membantu peserta didik untuk memperoleh pemahaman yang lebih mendalam tentang alam sekitar.

Pembelajaran IPA di sekolah dasar mengutamakan aktivitas siswa melalui berbagai kegiatan nyata dengan alam. Dengan berbagai aktifitas nyata maka siswa akan berhadapan langsung dengan fenomena yang akan dipelajari, dengan demikian berbagai aktifitas tersebut memungkinkan untuk terjadi proses pembelajaran yang aktif (Anjarsari, 2014). Penguasaan konsep IPA yang kurang disebabkan oleh kesulitan peserta didik dalam merespon pembelajaran yang diberikan oleh guru mereka. Banyak faktor yang mengakibatkan kesulitan dalam aktivitas belajar siswa. Menurut hasil penelitian Embun dan Astuti, 2015), media berpengaruh terhadap aktivitas dan hasil belajar siswa. Guru yang memberikan penjelasan tanpa menggunakan media akan memberikan dampak terhadap kurang aktifnya siswa dalam proses belajar. Hal ini ditemukan peneliti pada saat melakukan observasi di kelas IV SDI Onekore 4. Umumnya guru memberikan penjelasan kepada siswa secara abstrak dengan menunjukan contoh yang ada dalam buku teks. Keadaan tersebut juga turut mempengaruhi hasil belajar siswa.

Pembelajaran akan lebih bermakna jika siswa diberikan kesempatan untuk berpartisipasi dalam berbagai aktivitas kegiatan pembelajaran, sehingga siswa mampu mengaktualisasikan kemampuannya di dalam dan diluar kelas. Oleh karena itu, guru harus kreatif menggunakan semua potensi lokal ada sebagai sumber maupun media belajar (Susilo, 2015). Pembelajaran IPA di Sekolah Dasar yang dikembangkan menjadi alternatif bagi pendidik dalam memanfaatkan potensi lokal sebagai sumber belajar untuk menumbuhkan kepedulian peserta didik terhadap liingkungan (Lamahala dkk, 2018)). Dalam konteks pembelajaran IPA yang berhubungan dengan tumbuhan adalah dengan menerapkan media tanaman lokal.

Media adalah manusia, materi, atau kejadian yang membangun kondisi yang membuat siswa mampu memperoleh pengetahuan, keterampilan, atau sikap. Dalam pengertian ini guru buku teks dan lingkungan sekolah merupakan media. Secara lebih khusus pengertian media dalam proses belajar mengajar cenderung di artikan sebagai alat-alat grafis, photografis atau elektronik untuk menangkap, memproses dan menyusun kembali informasi visual dan verbal (Gerlach \& Ely dalam Sadirman 2010:15).

Tanaman lokal merupakan tanaman yang berasal dari kampung yang dapat memberikan khasiat atau manfaat bagi makhuk hidup 
khususnya manusia, tanaman lokal yang terdapat di Kabupaten Ende dan dapat diolah menjadi obat-obatan, contohnya seperti jahe, bawang merah, kunyit dan lain sebagainya. Jahe (zingiber officinale), adalah tanaman yang sangat populer sebagai rempah-rempah dan obat-obatan. Bawang merah atau Allium cepa L. Kelompok aggregatum merupakan salah satu bumbu masak utama dunia wujudnya berupa umbi yang dapat dimakan mentah, untuk bumbu masak, obat tradisional, kulit umbinya dapat dijadikan zat pewarna dan daunnya dapat pula digunakan untuk campuran sayur (Aryanta, 2019). Kunyit atau kunir, (Curcuna longa linn.syn.Curcuna domestica $\mathrm{Val}$ ) adalah salah satu tanaman rempahrempah dan obat asli dari wilayah Asia Tenggara yang dimanfaatkan untuk pengobatan herbal.

Sumber daya genetik tumbuh-tumbuhan mempunyai fungsi dan peranan yang penting dalam menunjang kehidupan manusia dimuka bumi, diantaranya sebagai sumber obat-obatan. Tumbuhan obat adalah tanaman yang bagian akar, batang dan daun yang mengandung senyawa bioaktif yang berkhasiat mengobati berbagai jenis penyakit (Hasan, 2019). Jenis tanaman ini dapat dimanfaatkan untuk pengobatan tradisional.

Di Indonesia terdapat berbagai jenis-jenis tanaman yang tersebar dari berbagai wilayah, tanaman-tanaman tersebut dapat dimanfaatkan sebagai bahan obat bagi masyarakat, salah satunya ialah tanaman obat berbasis lokal konten. Obat-obat herbal berbasis lokal konten berasal dari tumbuh-tumbuhan yang tersedia di lingkungan sekitar masyarakat local (Ayumanda \& Rahma, 2018). Sebagian masyarakat setempat telah menggunakannya sebagai obat-obat tradisional yang merupakan sarana penunjang kesehatan masyarakat secara turun temurun, bagian tanaman lokal ini yang digunakan adalah akar, batang dan daun tetapi tanaman obat ini belum terinvetarisasi dengan baik. Oleh karena itu perlu dilakukan kegiatan untuk melindungi dan menginvetarisasi tanaman obat yang ada

Berdasarkan urian diatas maka penulis melakukan penelitan dengan judul: Penggunaan Media Tanaman Lokal untuk Meningkatkan Aktivitas Belajar IPA di kelas
IV SDI Onekore 4 Kecamatan Ende Utara Kabupaten Ende Tahun Pelajaran 2019/2020.

\section{METODE PENELITIAN}

Penelitian ini merupakan penelitian tindakan kelas (classroom aktion research). Penelitian ini berfokus pada penggunaan media tanaman lokal untuk meningkatkan hasil belajar peserta didik pada pembelajaran IPA. Tahapan penelitian terdiri atas perencanaan, pelaksanaan tindakan, observasi dan refleksi.

Tahap perencanaan dilakukan dengan mempersiapkan instrumen penelitian, baik instrumen proses maupun instrumen hasil yang terdiri atas perangkat pembelajaran, lembar observasi aktivitas siswa dan tes hasil belajar. Persiaan perencanaan lainnya adalah menyiapkan media tanaman lokal yang disesuaikan dengan tujuan pembelajaran. Materi yang dipilih adalah mengenai hubungan antara struktur tumbuhan dan fungsinya dengan fokus pembelajaran pada struktur akar.

Tahap tindakan dilakukan dengan menerapkan media tanaman lokal sesuai langkah-langkah kegiatan pembelajaran dalam RPP. Saat tahap tindakan berlangsung, proses observasi juga turut dilaksanakan. Dalam penelitian ini penelit dibantu oleh satu orang observer untuk mengamati keterlaksanaan pembelajaran dan aktivitas belajar siswa.

Tahap terakhir merupakan refleksi. Refleksi dilakukan peneliti bersama observer untuk mengevaluasi kembali proses pelaksanaan pembelajaran yang telah dilakukan. Hasil refleksi juga menentukan apakah penelitian perlu dilanjutkan pada siklus berikutnya atau tidak.

Subyek dalam penelitian ini adalah peserta didik kelas IV SDI Onekore 4 dengan jumlah siswa 21 Orang yang terdiri dari lakilaki 12 orang dan perempuan 9 orang. Teknik pengumpulan data terdiri atas observasi, tes, dokumentasi dan wawancara. Observasi di gunakan untuk menangkap data yang berhubungan aktivitas belajar siswa. Instrumen observasi aktivitas pembelajaran siswa diadaptasi dari klasifikasi aktivitas menurut Diedrich (Sardiman, 2011:100). Aktivitas yang 
diamati terdiri dari aktivitas visual, mendengar, lisan, menulis, oral, dan mental. Tes digunakan untuk mengatahui peningkatan hasil belajar siswa. Dokumentasi digunakan untuk memperoleh data foto-foto saat pembelajaran berlangsung serta dokumendokumen yang merupakan data pendukung dlam penelitian ini. Sedangkan wawancara dilakukan untuk mendapatkan data pendukung dalam proses refleksi. Seluruh instrumen pengumpulan data divalidasi melalui proses validasi ahli.

Data yang terkumpul dianalisis secara deskriptif kualitatif dengan membandingkan ketuntasan aktivitas dan hasil belajar siswa setiap siklus berdasarkan pedoman acuan penilaian (PAP) pada Tabel 1. Untuk mengetahui ketuntasan tersebut, digunakan indikator kinerja. Apabila aktivitas siswa telah mecapai kriteria baik atau sangat baik, maka penerapan media tanaman lokal telah berhasil meningkatkan aktivitas belajar siswa.

Tabel 1. PAP Aktivitas Belajar Siswa

\begin{tabular}{ll}
\hline Persentase & Kategori \\
\hline $90 \%-100 \%$ & Sangat Baik \\
$80 \%-89 \%$ & Baik \\
$60 \%-79 \%$ & Cukup \\
$0 \%-59 \%$ & Kurang \\
\hline
\end{tabular}

\section{HASIL DAN PEMBAHASAN}

\section{A. Hasil Penelitian}

\section{Penerapan Media Tanaman Lokal}

Penelitian ini dilaksanakan dalam dua siklus dengan menerapkan media tanaman lokal. Proses penerapan media tanaman lokal dilakukan dengan beberapa langkah dengan mengadopsi pembelajaran berbasis inquiri. Langkah-langkah penerapan media tersebut antara lain:

a. Orientasi pengetahuan awal siswa mengenai jenis tanaman lokal di sekitar lingkungan siswa. Kegiatan ini dilakukan guru dengan bernyanyi bersama lagu "Lihat Kebunku”. Selanjutnya guru memberikan pertanyaan umpan balik mengenai pengetahuan awal siswa yang berhubungan dengan tanaman-tanaman lokal di sekitar tempat tinggal siswa. b. Mengajukan permasalahan dengan menunjukkan beberapa tanaman lokal. Guru menunjukkan beberapa tanaman lokal dan menanyakan pada siswa mengenai struktur akar dan manfaat dari tanaman tersebut.

c. Membimbing siswa menulis hipotesis berdasarkan bentuk akar dan manfaat tanaman lokal. Kegiatan ini dilakukan dengan mengelompokkan siswa ke dalam beberapa tim . siswa diminta untuk berpikir dan menuliskan dugaan jawaban atau hipotesis ke dalam worksheet yang disediakan.

d. Membimbing siswa dalam mengamati bentuk akar dari media yang telah disiapkan. Guru membagikan media tanaman lokal dan meminta siswa membuktikan hipotesisnya melalui proses pengamatan struktur akar media tersebut.

e. Membimbing siswa dalam membuat kesimpulan dari hasil pengamatan

Selama pembelajaran dengan langkah tersebut dilakukan pengamatan terhadap keterlaksanaan pembelajaran, yang hasilnya dapat dilihat pada Tabel 2. Dalam Tabel 2 menunjukkan bahwa pada siklus 1 keterlaksanaan pembelajaran berada dalam kategori baik. Sedangkan pada siklus 2 keterlaksanaan pembelajaran dengan media tanaman lokal menunjukkan pningkatan dengan kategori sangat baik.

Tabel 2. Keterlaksanaan Pembelajaran

\begin{tabular}{|c|c|c|}
\hline Langkah Pembelajaran & $\begin{array}{c}\text { Siklus } \\
1 \\
\end{array}$ & $\begin{array}{l}\text { Siklus } \\
2 \\
\end{array}$ \\
\hline $\begin{array}{l}\text { Orientasi pengetahuan awal siswa } \\
\text { mengenai jenis tanaman lokal di } \\
\text { sekitar lingkungan siswa }\end{array}$ & baik & $\begin{array}{l}\text { Sangat } \\
\text { baik }\end{array}$ \\
\hline $\begin{array}{l}\text { Mengajukan permasalahan dengan } \\
\text { menunjukkan beberapa tanaman } \\
\text { lokal }\end{array}$ & baik & $\begin{array}{l}\text { Sangat } \\
\text { baik }\end{array}$ \\
\hline $\begin{array}{l}\text { Membimbing siswa menulis } \\
\text { hipotesis berdasarkan bentuk akar } \\
\text { dan manfaat tanaman lokal }\end{array}$ & baik & $\begin{array}{l}\text { Sangat } \\
\text { baik }\end{array}$ \\
\hline $\begin{array}{l}\text { Membimbing siswa dalam } \\
\text { mengamati bentuk akar dari media } \\
\text { yang telah disiapkan }\end{array}$ & baik & $\begin{array}{l}\text { Sangat } \\
\text { baik }\end{array}$ \\
\hline $\begin{array}{l}\text { Membimbing siswa dalam membuat } \\
\text { kesimpulan dari hasil pengamatan }\end{array}$ & baik & $\begin{array}{l}\text { Sangat } \\
\text { baik }\end{array}$ \\
\hline
\end{tabular}




\section{Aktivitas Belajar Siswa}

Aktivitas belajar yang diamati merupakan jenis aktivitas belajar yang merujuk pada pendapat Diedrich. Jenis aktivitas tersebut antara lain aktivitas oral atau aktivitas lisan, aktivitas visual, aktivitas mendengar, aktivitas menulis dan aktivitas mental. Aktivitas tersebut telah disesuaikan dengan tujuan dalam penelitian ini dan terangkum dalam Tabel 3.

Tabel 3 Jenis Aktivitas Belajar siswa

\begin{tabular}{ll}
\hline \multicolumn{1}{c}{$\begin{array}{c}\text { Indikator Aktivitas } \\
\text { Belajar }\end{array}$} & \multicolumn{1}{c}{ Deskripsi } \\
\hline aktivitas oral & $\begin{array}{l}\text { Menjawab pertanyaan } \\
\text { umpan balik guru, }\end{array}$ \\
& $\begin{array}{l}\text { berdiskusi dengan anggota } \\
\text { kelompok lain }\end{array}$ \\
aktivitas visual & $\begin{array}{l}\text { Mengamati dengan teliti } \\
\text { jenis akar tanaman }\end{array}$ \\
aktivitas mendengar & $\begin{array}{l}\text { Mendengarkan instruksi } \\
\text { dari guru }\end{array}$ \\
aktivitas mental & $\begin{array}{l}\text { Menganalisa jenis akar dari } \\
\text { tanaman lokal yang } \\
\text { disajikan r dan }\end{array}$ \\
& $\begin{array}{l}\text { Menulis hipotesis r dasil } \\
\text { kesimpulan } \\
\text { pengamatan }\end{array}$ \\
\hline
\end{tabular}

Hasil pengamatan aktivitas belajar pada Tabel 3 selama dua siklus tertuang dalam grafik pada Gambar 1.

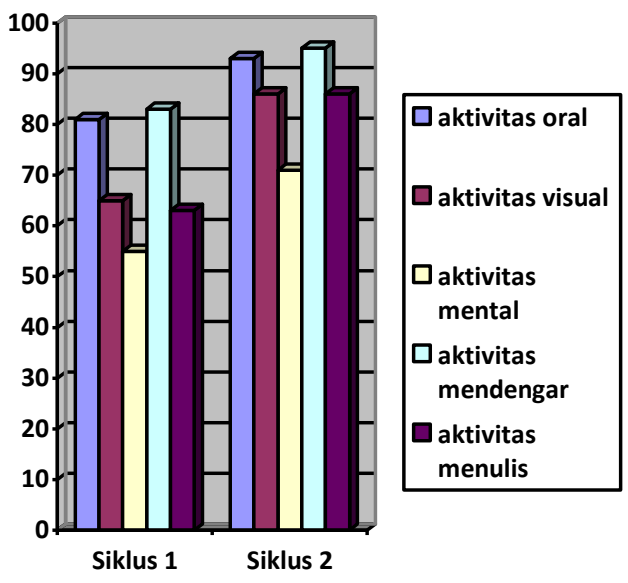

Gambar 1 Hasil Observasi Aktivitas belajar siswa

Data pada Gambar 1 menunjukkan bahwa aktivitas oral siswa pada siklus 1 sebesar $81 \%$ dan meningkat menjadi $93 \%$ pada siklus 2. Aktivitas visual siswa pada siklus 1 sebesar $65 \%$ dan meningkat menjadi $6 \%$ pada siklus 2. Sedangkan aktivitas mentas siswa berada dalam persentase $55 \%$ pada siklus 1 dan meningkat menjadi $71 \%$. Adapun aktivitas mendengar memperoleh peningkatan sebesar $83 \%$ di siklus 1 dan menjadi $95 \%$ di siklus 2 . Sedangkan aktivitas menulis memproleh $63 \%$ pada siklus 1 dan meningkat menjadi $86 \%$ pada siklus 2.

Perolehan persentase pada Gambar 1 kemudian dikonversikan sesuai PAP dalam Tabel 1. Hasil konversi tersebut terangkum dalam Tabel 4

Tabel 4 Aktivitas Belajar Siswa

\begin{tabular}{lll}
\hline \multicolumn{1}{c}{ Aktivitas Belajar } & $\begin{array}{l}\text { Siklus } \\
\mathbf{1}(\boldsymbol{\%})\end{array}$ & $\begin{array}{l}\text { Siklus } \\
\mathbf{2}(\boldsymbol{\%})\end{array}$ \\
\hline $\begin{array}{l}\text { Menjawab pertanyaan umpan } \\
\text { balik guru, berdiskusi dengan }\end{array}$ & Baik & Baik \\
$\begin{array}{l}\text { anggota kelompok lain } \\
\begin{array}{l}\text { Menulis hipotesis dan } \\
\text { kesimpulan hasil pengamatan } \\
\text { Mengamati dengan teliti jenis }\end{array}\end{array}$ & Cukup & Sekali \\
$\begin{array}{l}\text { akar tanaman } \\
\begin{array}{l}\text { Menganalisa jenis akar dari } \\
\text { tanaman lokal yang disajikan }\end{array}\end{array}$ & Kurang & Cukup \\
$\begin{array}{l}\text { Mendengarkan instruksi dari } \\
\text { guru (aktivitas mendengar) }\end{array}$ & Baik & Baik \\
\hline
\end{tabular}

Pada siklus 1 aktivitas oral, dan aktivitas mendengar berada dalam kategori baik. Sedangkan aktivitas visual dan aktivitas menulis berada dalam kategori cukup. Adapun aktivitas mental masih berada dalam kategori kurang. Berdasarkan rata-rata aktivitas pembelajaran yang telah dikonversikan ke dalam pedoman acuan penilaian (PAP), aktivitas siswa dalam siklus I masih dalam kategori cukup.

Pada siklus 2, seluruh aktivitas mengalami peningkatan seperti aktivitas oral dan aktivitas mendengar berada dalam kategori sangat baik. Aktivitas menulis dan aktivitas visual berada dalam kategori baik. Sedangkan aktivitas mental meningkat dalam kategori cukup. Adapun rata-rata keseluruhan aktivitas berdasarkan konversi PAP berada dalam kategori baik. Berdasarkan pencapaian tersebut 
maka disimpulkan penerapan media tanaman lokal dapat meningkatkan aktivitas belajar siswa.

\section{Hasil Belajar Siswa}

Data hasil belajar dalam penelitian ini diperoleh melalui tes. Tes yang diberikan merupakan tes kognitif. Tes diberikan setelah tindakan. Adapun hasil belajar siswa setelah melalui pembelajaran dengan menerapkan media tanaman lokal dalam siklus 1 disajikan dalam Gambar 2.
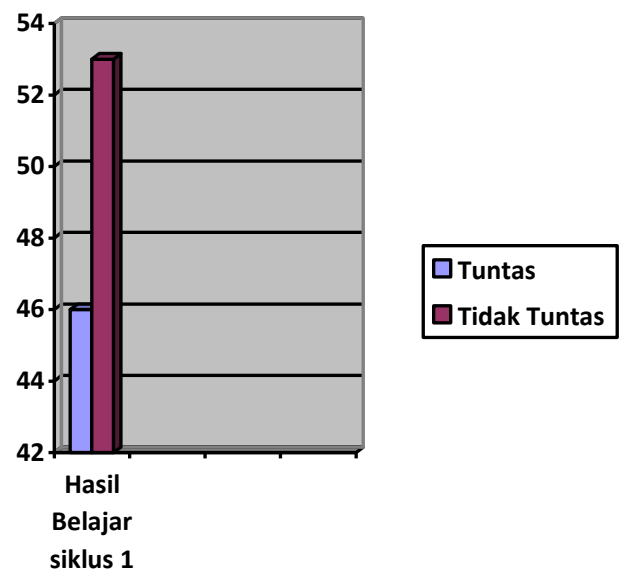

Gambar 2 Hasil Belajar siswa siklus 1

Dalam siklus 1 diketahui bahwa 46\% siswa sudah mengalami ketuntasan. Sedangkan $53 \%$ atau sebagian besar siswa belum mengalami ketuntasan belajar. Data hasil tes tersebut direfleksikan bersama oleh peneliti dan observer. Data tes hasil belajar juga digunakan sebagai data pendukung dalam menentukan pelaksanaan siklus selanjutnya. Berdasarkan hasil refleksi hasil tersebut belum sesuai dengan target yang ingin dicapai dalam penelitian ini. Sehingga diputuskan untuk dilaksanakan kembali proses pembelajaran pada siklus 2 .

Pada tes hasil belajar di siklus 2 diperoleh data hasil belajar sebagaimana yang tertera dalam Gambar 3
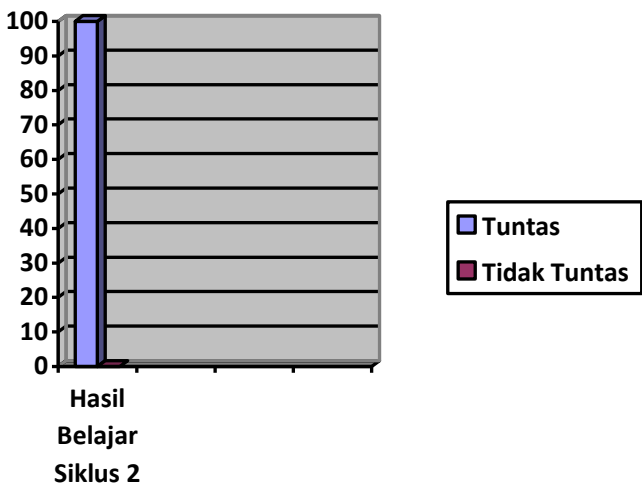

Gambar 3 hasil Belajar siswa siklus 2

Pada Gambar 3 menunjukkan pencapaian ketuntasan belajar sebesar 100\% setelah diterapkan media tanaman lokal. Pencapaian tersebut telah sesuaidengan target penelitian ini. Sehingga penelitian tidak dilanjutkan ke siklus selanjutnya karena penerapan media tanaman lokal telah meningkatkan hasil belajar siswa pada siklus kedua.

\section{B. Pembahasan}

Proses pembelajaran IPA semestinya dapat menyentuh kehidupan sehari-hari siswa agar lebih bermakna. Hal senada diungkap Laksana dan Wawe (2015), bahwa pembelajaran akan lebih bermakna apabila siswa memperoleh pengetahuan melalui lingkungan sosialnya. Namun dalam prakteknya, di SDI Onekore 4 belum menunjukkan indikasi tersebut. Keadaan ini menyebabkan siswa menjadi pasif dan terkesan menghafal konten pembelajaran. Hal tersebut ikut berdampak pada menurunnya hasil belajar siswa.

Untuk mengatasi permasalahan pembelajaran IPA di kelas IV SDI Onekore 4, maka diterapkanlah media tanaman lokal. Tanaman lokal merupakan tanaman yang tumbuh di sekitar lingkungan siswa dan sering dimanfaatkan dalam kehidupan sehari-hari. Penggunaan media tanaman lokal yang familiar dengan siswa sehingga dapat menjadi penghubung bagi siswa dalam memahami dan memaknai proses belajar. Hal ini terbukti setelah siswa melalui proses belajar dalam dua 
siklus dimana terjadi peningkatan aktivitas dan hasil belajar siswa.

Penggunaan media tanaman lokal dalam penelitian ini cukup meransang antusiasme siswa. Hal ini dikarenakan guru memberikan orientasi awal untuk membangkitkan minat siswa. Kegiatan orientasi awal dilakukan dengan menggali pengetahuan awal siswa mengenai jenis tanaman lokal yang ada di sekitar siswa. Pada fase ini melibatkan aktivitas oral siswa dalam menjawab pertanyaan guru. Siswa terekam aktif menjawab pertanyaan guru pada siklus 1 dan meningkat sangat aktif pada siklus 2 .

Melalui penerapan media tanaman lokal, siswa dilatih untuk menuliskan hipotesisnya terhadap permasalahan yang diajukan oleh guru. Hal ini memacu siswa untuk dan aktif dalam dalam menuangkan ide berdasarkan media yang familiar dengan kehidupan sehariharinya. Melalui hal tersebut siswa dilatih untuk berpikir kritis dan peka terhadap keadaan dan nilai lokal di lingkungan sekitarnya. Aktivitas ini mendapat predikat cukup pada siklus 1 dan meningkat menjadi baik pada siklus 2 .

Aktivitas visual dalam penelitian tercermin dalam kegiatan siswa saat melakukan pengamatan terhadap struktur akar dari tanaman lokal. Dalam proses ini siswa dilatih untuk teliti mengamati dan mengklasifikasikan berbagai bentuk akar sesuai jenisnya. Dalam aktivitas ini rata-rata sisa memperoleh kategori cukup pada siklus 1 dan meningkat dalam kategori baik pada siklus 2 .

Dalam aktivitas mendengar, yakni mendengarkan instruksi dari guru dilakukan dengan baik oleh siswa pada siklus 1 . Sedangkan dalam siklus 2 aktivitas ini meningkat menjadi sangat baik.

Walaupun penelitian ini telah berhasil meningkatkan aktivitas dan hasil belajar siswa, dalam pelaksanaana masih ditemukana kelemahan yang menjadi keterbatasan dalam penelitian ini. Kelemahan tersebut salah satunya adalah membutuhkan waktu yng banyak. Hal ini dikarenakan terdapat aktivitas mental dimana siswa diminta untuk mengobservasi dan menganalisa jenis-jenis akar sesuai media yang disiapkan. Sebelumnya siswa tidak terbiasa dengan aktivitas ini sehingga guru juga banyak memberikan bantuan pada tahap ini. Deskripsi keadaan ini sejalan dengan data aktivitas mental siswa pada Tabel 4 dimana perolehan aktivitas ini paling rendah, baik pada siklus 1 maupun pada siklus 2.

\section{SIMPULAN DAN SARAN}

Berdasarkan hasil penelitian dapat disimpulkan bahwa penggunaan media tanaman lokal dapat meningkatkan aktivitas IPA pada siswa kelas 4 SDI Onekore 4. Peningkatan aktivitas tersebut terlihat dari siklus 1 ke siklus 2 yang terdiri atas aktivitas oral, aktivitas mental, aktivitas visual, aktivitas mendengar dan aktivitas menulis.

Penerapan media tanaman lokal juga meningkatkan hasil belajar IPA yang dapat dilihat dari ketuntasan belajar siswa pada siklus 1 sebesar $46 \%$ dan meningkat menjadi $100 \%$ pada siklus 2 .

\section{DAFTAR PUSTAKA}

Anjarsari, P. 2014. Literasi Sains Dalam Kurikulum Dan Pembelajaran IPA SMP. Prosiding Semnas Pensa VI "Peran Literasi Sains" Surabaya, 20 Desember 2014

Aryanta, I.M. 2019. Bawang Merah Dan Manfaatnya Bagi Kesehatan. E-Jurnal Widya Kesehatan, Volume 1, Nomor; 1

Ayumanda, D., \& Rahma, E. 2018. Paket Informasi Obat-Obat Herbal Berbasis Lokal Konten Di Kecamatan Koto Tangah Kota Padang. Jurnal Ilmu Informasi Perpustakaan dan Kearsipan Vol. 7, No. 1, 32-39

Embun, S. \& Astuti, M. 2015. Pengaruh Penggunaan Media Gambar Terhadap Aktivitas Belajar Siswa Pada Mata Pelajaran IPA Materi Bumi Dan Cuaca Di Madrasah Ibtidaiyah Najahiyah Palembang. Jurnal Ilmiah PGMI, 1(1), 81-107

Hasan, M.S. 2019. Pemanfaatan tanaman lokal untuk apotek hidup di Kecamatan Watang Sidenreng Kabupaten Sidrap. 
Seminar Nasional Pengabdian Kepada Masyarakat, 2019 . Univeristas Negeri Makassar.

Lamahala, M.H., Lamen, S. \& Uslan. 2018. pengembangan Media Jaringan Epidermis Tanaman Jagung (Zea mays L.) Yang Tumbuh Di Kota Kupang Sebagai Sumber Belajar Tambahan Pembelajaran IPA SD Berbasis Kearifan Lokal. Jurnal Ilmiah Pendidikan Citra Bakti 5 (2), 15-25.

Purbosari, P.M. 2016. Pembelajaran Berbasis Proyek Membuat Ensiklopedia Ilmu Pengetahuan Alam (IPA) Untuk Meningkatkan Academic Skill Pada Mahasiswa. Scholaria, 6(3), 231-238

Sardiman. 2006. Interaksi dan motivasi belajar mengajar. Jakarta:Rajawali.

Susilo, M.J. 2015. Identifikasi Tumbuhan Berbiji (Spermatophyta) Sebagai Materi Pembelajaran IPA-BIOLOGI SMP Berbasis Potensi Lokal Di Kawasan Pasir Pantai Depok Kabupaten Bantul. Prosiding 